\section{Kindergartens and Their Removal from the State Sector Act}

\section{Claire DAVison}

\section{Abstract:}

The kindergarten sector has been the scene of some remarkable policy manoeuvres over the past seven years. Successive Governments in New Zealand have sought to implement a "New Right" agenda aimed at reducing state involvement in the sector. In 1997 we have witnessed some decisive moves in this direction. This paper focuses on the removal of kindergartens from the State Sector Act 1988, through an Amendment to the Act passed in April, 1997.

$\mathrm{T}$ he kindergarten sector has been the scene of some remarkable policy manoevres over the past seven years. Unexpected Government initiatives have taken the kindergarten community unawares, policies have been announced and altered, statements made and then amended. A clear ideological agenda underlying these moves has evidently driven Government policy in relation to the kindergarten sector since 1990.

In this paper, the political and economic conditions which gave rise to the New Right ideology are identified, and recent developments in Government policy for kindergartens are discussed, with particular reference to views expressed by key participants. But the major focus, however, is on the removal of kindergarten associations and their employees from the State Sector Act, by means of an Amendment passed in April 1997.

\section{Kindergarten Background and Government Involvement in the Sector}

There is some evidence of free kindergartens in New Zealand in the late 1870 s, but "the first kindergarten for which there is any substantive record opened in Dunedin in 1889" (May, 1997). It was set up voluntarily by a group concerned for the well-being of pre-school children. Funds raised by the group enabled a trained teacher to be employed, and provided the first free early childhood education in New Zealand. The idea spread, and kindergartens adhering to the same philosophy were opened throughout the country. Each kindergarten employed only trained teachers, and provided free education. These two components have been essential to kindergarten philosophy ever since.

Government support of kindergartens has taken a variety of forms. The first Government contribution, made in 1904, was in the form of a one-off grant distributed between the main city centres. A pound-forpound subsidy on monies collected was offered in 1909.

In 1947, the Consultative Committee on Pre-School Educational Services (the Bailey Committee) released its report on early childhood education in New Zealand. The report recommended the development of a national pre-school system. This system was to be funded and controlled by the State and regarded as part of the national school system (May, 1997). Whilst this recommendation was not fully adopted, it did encourage the government of the day to become actively involved with the kindergarten movement, paying kindergarten teacher salaries and setting conditions of service from 1948.

It has generally been accepted that kindergarten teachers have been state servants since this time. Their salaries were determined under processes laid out in education legislation until 1969, when the Government passed the State Services Remuneration and Conditions of Employment Act. This Act gathered all state services together and subsequently became the State Services Conditions of Employment Act 1977. This Act preceded the State Sector Act 1988. Kindergarten teachers have been specifically included in this state servant definition until April 1997.

However, Government involvement in the kindergarten sector extended, over time, to cover more than the payment of salaries and setting of conditions. In 1992, Wylie noted that, "kindergartens have been the flagship for Government support for New Zealand early childhood education" (Wylie, 1992, p. 2). She described this support as including

... $80 \%$ of building costs (with a limit of six new kindergartens a year) free building sites (until 1990), actual teacher salaries, a national career structure, some support for the national network of employing associations (the Free Kindergarten Union) and a national system of professional support through senior teachers. (p. 2) 
By 1990, there were 575 New Zealand kindergartens, which had developed a reasonably uniform, nationwide service. Kindergartens operated on a sessional basis and children were generally aged between three and five years. Up to forty children were enrolled in each session. Kindergartens remained free, with parents being asked to make a voluntary donation. Parents paid according to their ability, with some making little or no financial contribution.

Individual kindergartens were run by local committees comprising elected parents. Regional bodies, known as kindergarten associations, were made up from parents elected from the local committees. The nationwide body (referred to by Wylie above), the New Zealand Free Kindergarten Union (NZFKU), which had been established in 1926, was formed from regional association representatives (May, 1997).

In 1997, there were 595 kindergartens nationwide, catering for 46,756 children (Ministry of Education, 1997c).

\section{An Ideological Shift and Changed Economic and Political Conditions}

During the mid-1970s, the New Zealand economy showed signs of stress and shortfalls in performance (Crocombe, Enright \& Porter, 1991; Kelsey, 1993, 1995). The economy had previously relied on the sale of agricultural commodities to protected markets and involved extensive government intervention. The oil shocks, Britain's developing commitment to the European Economic Community and the failure of the New Zealand Government's "Think Big" projects compounded this stress.

New Zealanders were dissatisfied with growing debt, unemployment and inflation, and in the 1984 Election the fourth Labour Government came to power. This Labour Government announced that the country faced an economic crisis, and immediately devalued the currency by 20 percent. This crisis situation provided the opportunity for the new Government to focus on economic considerations and eased the way for a programme of widespread, radical reform.

The philosophy on which this reform was based was that of the recently-evolved New Right (or liberal) ideology which was becoming influential internationally amongst a growing group of economists. It derived from a concern about declining profitability and involved moving towards a radically deregulated economy, driven by market forces (Kelsey, 1993).

This ideology focusses on the pursuit of self interest, emphasising individual freedom through lack of regulation or intervention.
Economic efficiency is given high priority and promoted through choice and competition. There is a belief that the free market is the best means of regulation and that the provision of a welfare state disrupts the operation of the market. The state is considered to stifle or crowd out the private sector, and its institutions are believed to be inefficient monopolies because they are not subject to the market (Lauder, 1990).

The outcome of these beliefs is that New Right advocates promote choice and competition, reduced public expenditure, a reduced welfare state, the sale of state assets and the privatisation of state businesses. Those who cannot succeed in the market place should be allowed to fail.

The fourth Labour Government adopted this ideology, but its moves with regard to education and the kindergarten sector were tempered by strong considerations of equity. When the National Government came to power in October 1990, the framework for such an ideology was already established. The National Government took a more hard-line approach and the kindergarten sector came under increasing pressure from this time.

\section{New Right Ideology and the Kindergarten Sector}

The view of the New Zealand Treasury typified the New Right view of early childhood care and education. The 1987 briefing papers expressed the view that parents were the prime benefactors of early childhood care and education and as such should meet the costs of those services. The encouragement of alternative providers was advocated, with emphasis on targeted funding to accompany the user-pays focus. Funding was to be attached to the child rather than the provider, to promote choice. The Treasury view was that the cost of provision had been increased by needless over-professionalisation of personnel (Treasury, 1987)

Kindergarten sector operation certainly did not comply with new ideology. Kindergartens had historically relied on state support for funding salaries, buildings and equipment. They provided a sessional mode of operation, rather than all-day care which would release parents to participate in the labour market. They provided a service which was ostensibly free (refusing to charge fees) and insisted on employing only trained, registered teachers.

\section{Developments in Kindergarten Policy}

Education to be More (ECCE Working Group, 1988) was a progressive report on early childhood care and education. It advocated high quality 
provision and emphasised equity in both access to, and state funding of, early childhood services. The recommended method was bulk grant funding, based on the same hourly rate for all quality services. The funding rate was to be raised to at least the level of kindergarten funding, significantly higher than that received by most other services at the time. Before Five (Lange, 1988), the Government's policy document in response to Education to be More, accepted the need for high quality services, funded at a reasonable rate. Staged funding increases were planned. The aim of these increases was that all chartered early childhood services would be funded at the same rate by 1994/5.

The first payment of the bulk grant was made in February 1990. Kindergartens at this time received only the operations component of the bulk grant. Teacher salaries remained directly paid. The early childhood reforms to this date had impacted on kindergartens to the extent that Education Boards had been disbanded and regional associations were now responsible for managing their operations grant. The staged funding increases however, had not yet affected kindergartens.

Two months after coming to power in 1990, the National Government released its Economic and Social Initiative (Bolger, Richardson \& Birch, 1990). This initiative made explicit the National Government's desire to adopt the New Right ideology and to review provision in the early childhood sector. The staged funding increases were halted and four reviews of the sector were announced. Two days later, legislation was passed unexpectedly, enabling kindergartens to charge fees (Education Amendment Act No. 3, 1990). This radical departure from kindergarten philosophy caused concern within the sector, but associations nevertheless reiterated their refusal to restrict access by fee charging.

The 1991 Budget capped kindergarten funding at the 1991 level, removed compulsory kindergarten teacher registration and introduced kindergarten salary bulk funding. The introduction of kindergarten bulk funding was another surprise move which was met with anger and concern from the kindergarten community. Irrespective of this concern, implementation commenced in March, 1992.

The key concerns of the kindergarten community were that bulk funding would enable Government to devolve the responsibility for kindergarten provision to the regional associations, and that the method of funding would provide Government with a ready mechanism for driving down the level over time. These concerns were heightened when the Early Childhood Care and Education Funding Review was released (ECCE Funding Review Committee, 1991). This review showed a marked deviation from the Before Five philosophy of bringing all other early childhood services' funding up to the level of kindergartens. The emphasis now was to bring kindergarten funding down to the same, lower level as other services. From this time onwards the aim of funding policy for the early childhood sector has been to develop a system that is neutral as to provider, and to fund all services at the same rate.

The halting of staged funding increases indicated the Government's intention to review its role in funding the sector. The provision for kindergartens to charge fees emphasised the acceptance of user-pays and private gain tenets; the capping of kindergarten funding and the imposition of bulk funding indicated Government's desire to withdraw from responsibility for the sector; the removal of compulsory teacher registration was designed to avoid over-professionalisation of workers in the sector; and the neutral funding aim evidenced the desire to encourage alternative providers to take responsibility for provision.

Successive speeches by the Ministers responsible for Early Childhood Education reiterated the need for kindergartens to change their mode of operation (Luxton, 1994; English, 1996). Changes to kindergarten policy endeavoured to make kindergartens operate more like private, child care services; opening for longer hours, charging fees and reducing their reliance on the State.

The 1995 Budget offered kindergartens two choices. They could either take a minimal 0.87 percent increase in funding (New Zealand Educational Institute, 1995) or reduce their hourly rate from $\$ 2.875$ per child/hour to $\$ 2.50$ and claim for more hours. No associations elected to take the reduced rate.

The funding policy was changed three times in 1996 after pressure from the kindergarten community. The Budget in May set a 2.5 percent increase to the hourly rate, taking it from $\$ 2.90$ to $\$ 2.975$ (effective January 1, 1997). This was altered by the announcement of a new package on July 27 , which kept the previous option but also gave associations the ability to access forty extra funded sessions if they remained at the lower, $\$ 2.90$ rate. This was altered for the third time on September 23, when yet another package announced that the funding rate would be increased from $\$ 2.90$ to $\$ 3.09$ as of January 1, 1997.

These changes were made after strong lobbying for funding increases. The combined strength of a relatively small community consisting of kindergarten teachers, the New Zealand Educational 
Institute, parents, and kindergarten associations, had proved to be effective.

\section{The Kindergarten Sector and the State Sector Act 1988}

Bulk funding had placed kindergartens on the same basis of funding as other early childhood services (although still at a higher hourly rate). But the State Sector Act stated that kindergartens and kindergarten teachers were part of the state sector, implying a certain degree of government responsibility and support. Whilst bulk funding had provided the mechanism for government to devolve responsibility, the State Sector Act emphasised this responsibility, and distinguished kindergartens from other early childhood services. This conflict was problematic for policy makers aiming for neutral government funding and reduced government involvement.

As kindergarten teachers were education sector state servants, the State Services Commissioner was responsible for negotiating their collective employment contracts (CECs). In 1994, the Government empowered the State Services Commissioner to delegate this authority to kindergarten associations. The Auckland Kindergarten Association (AKA) was the only association to accept this delegation, doing so from 1995. On July 1, 1997 the responsibility to negotiate education sector CECs was to be transferred to the Secretary for Education. Cabinet made it clear, however, that delegation to kindergarten associations, the recipients of the bulk grant, was the long-term goal. The State Services Commission (SSC) has therefore negotiated contracts with Government on behalf of kindergarten associations (except the AKA). This arrangement has meant that settlements agreed to by the SSC could be imposed upon them.

One of the levers used to gain increases to kindergarten funding, against the ideological trend, has been the requirement that kindergarten associations fund the pay increases agreed in CEC settlements. Kindergarten teachers, as state servants, had argued that Government had the responsibility to provide the funding for agreed pay increases.

This argument proved successful in the 1996 CEC negotiations when Budget funding decisions were altered to increase the hourly rate for kindergartens, and fund a one-off payment for kindergarten teachers. Officials have noted the importance of this. The Treasury commented:
The SSC's current role in wage bargaining allows both the kindergarten associations (the employers) and the NZEI to use wage rounds to pressure the Government to provide additional budget funding relative to that available to other providers. This reduces incentives for kindergartens to provide services that are responsive to the demands of parents, to maximise other sources of income and to improve their efficiency. (Treasury, 1997a)

The Minister of State Services stated that:

The significant risk associated with the current role required of the SSC under the Act is that it provides the kindergarten sector (kindergarten employers indicated their support in 1996 for the NZEI pay parity claim) the opportunity to pressure Government through their wage negotiations to alter Budget decisions taken on overall EC funding to the advantage of kindergartens. This occurred in the 1996 wage negotiations where, in order to persuade employers to agree to put forward a wage offer which could be perceived as reasonable, the funding rate for 1997 for kindergartens has increased. (Minister of State Services, 1997a)

In November 1995, the Education and Science Select Committee held hearings in response to 264 petitions (containing more than 16,000 signatures) requesting an increase to kindergarten funding (Mitchell, 1996). The Hon. John Luxton, the Minister responsible for the early childhood sector at the time, attended one session. At this hearing, Ministry of Education (MOE) officials responded to kindergarten associations' requests for salary increases to be compensated in the bulk grant by stating that although the SSC negotiates on behalf of the associations, this did not oblige the Government to fund any increase which might be agreed. The Minister said that it was doubtful whether kindergarten teachers were covered by the State Sector Act, and the MOE officials were asked to provide clarification of this issue. The clarification (Ministry of Education, 1995) confirmed that under the terms of the State Sector Act 1988, kindergarten teachers were indeed considered to be state servants. It was confirmed that kindergarten teachers and kindergartens were part of the state sector and that Government therefore had some responsibility to fund them and comply with the principles of being a good employer. Kindergarten associations understood that this provision afforded them some protection. They were therefore opposed to any moves which would remove kindergarten teachers from the State Sector Act or force associations to accept the SSC delegation. 
This position was brought to the attention of MOE officials in 1995, but it became clear by 1997 that they believed that this was problematic. It enabled kindergartens to exert pressure on Government for increased funding, thereby gaining an advantage over other early childhood services. At a time when the rest of the sector was receiving lower rates of government funding, and when the policy direction was to aim for neutral early childhood funding, this was clearly unacceptable.

The aim of reduced Government responsibility, or Government withdrawal, from the early childhood sector was clearly threatened if kindergartens remained under the provisions of the State Sector Act 1988. Government's ability to limit funding to the same levels as other early childhood providers was being tested by the kindergarten sector, and the Act was being used to emphasise Government's responsibility for kindergartens. The increases to kindergarten funding were enabling associations to maintain their operation and resist pressures to conform to the doctrines of fee charging, extending hours and employing untrained or lesser-trained teachers.

\section{The Removal of Kindergartens from the State Sector Act 1988}

On April 29, 1997, kindergarten employers and the New Zealand Educational Institute (NZEI) were invited to meet with Hon. Jenny Shipley, Minister of State Services, to discuss "bargaining arrangements for the forthcoming round" (personal correspondence from Hon. Jenny Shipley to kindergarten association representatives, April 24, 1997). The expectation was that the management of the negotiations would be discussed. The State Services Commissioner had confirmed with NZEI on March 7, 1997 that despite the impending transfer of responsibility for education sector negotiations to the Secretary of Education on July 1, 1997, the SSC would negotiate the kindergarten teachers' collective employment contract, due to expire prior to that date. NZEI and the employers therefore had no doubts at this stage as to which parties would be involved in negotiations.

The Minister of State Services, however, informed the group that the "Government will today introduce legislation into Parliament to remove kindergartens from the coverage of the State Sector Act", and that they would be "seeking Parliamentary agreement to using urgency provisions of Standing Orders so as to give effect to the change" (personal correspondence from Hon. Jenny Shipley to kindergarten association representatives and NZEI, April 29, 1997).
The announcement was completely unexpected, and employers and NZEI were outraged. The effect of such a Bill was that kindergarten teachers would no longer be considered state servants. It would remove the SSC from negotiations, thereby severing the link with Government, and force kindergarten associations to negotiate directly with NZEI. The use of urgency provisions meant that the Bill was not to be subject to scrutiny or submissions through the Select Committee process. The Bill could therefore be passed in Parliament very swiftly and without consultation with the kindergarten sector.

As described already, the State Sector Act 1988 had provided protection for teachers and associations in previous negotiations. Both parties were keen to remain under its jurisdiction. But the new Bill was introduced under urgency that day, and became law the following day, April 30, 1997. The passing of the Act immediately took kindergarten teachers out of the state sector and removed Government from responsibility for negotiating and funding kindergarten teachers' salaries.

The implications of removal from the Act were, however, more farreaching than the alteration to bargaining, and the reduced responsibility of Government. Kindergarten associations became directly involved in costly and complex negotiations. Funding constraints made it likely that negotiations would result in tensions with teachers, damaging the relationship with the associations and weakening the kindergarten community's previous combined strength. Kindergarten teachers' status in the state sector was lost, and pay parity and the maintenance of qualification levels became less certain. The costs of future funding shortfalls were now to fall upon local communities, and the need to charge fees would become pressing. Kindergarten teachers contributing to the Government Superannuation Scheme were at some risk of exclusion. (Assurances were subsequently received that this would not eventuate and that current arrangements would be honoured). Kindergarten associations would no longer be covered by the "good employer" or EEO provisions of the Act although they would continue to be bound by the requirements of the "Desirable Objectives and Practices" gazetted by the Minister of Education in 1990.

The reason given for seeking urgency was to give associations "the maximum time to prepare for wage negotiations associated with the current CECs which expire on 30th June" (personal communication from Hon. Jenny Shipley to kindergarten association representatives, April 29, 1997). Urgency procedures, circumventing the Select 
Committee process, avoided public submissions on the Bill. A Memorandum for the Cabinet Committee on Legislation and House Business stated that

... the Bill as a whole will be contentious. Both NZEI and kindergarten associations are likely to strenuously oppose the Bill through the Parliamentary process. This is also likely to coincide with a public campaign accompanied by community action. Kindergarten closures are a possibility. (Minister of State Services, 1997b)

Invoking urgency procedures precluded such actions. Kindergarten teachers were unable to strike legally before the expiry of their CEC (June 30, 1997) and were required even then to give fourteen days notice of strike action. NZEI co-ordinated action at short notice, including a nationwide petition, but this had little effect on the passing of the Bill.

Papers later released under the Official Information Act revealed that the Cabinet Committee on Education and Employment Policy had in fact been examining the removal of kindergartens from the State Sector Act as early as February 26, 1997 (EEP, 1997). If concern that kindergarten associations needed time to prepare for the forthcoming negotiations in June was the real reason for using urgency procedures, then it would have been a simple matter for Government to have informed associations of their intention to alter the bargaining arrangement prior to April 29, 1997, the day that the Bill was introduced to Parliament. The fact that they did not choose to do so confirms that the real reason for invoking urgency was to maintain secrecy, avoid confrontation and minimise public input.

Cabinet agreed on the April 14, 1997, to provide an assistance package for kindergarten associations for 1996/97. This package was intended to assist associations with the legal and advocacy costs which they would incur in their new role. There was debate amongst Treasury, MOE and SSC officials and the package finally agreed on was a $\$ 236,000$ (GST inclusive) cash contribution allocated on a pro rata basis to associations. Of this sum, $\$ 10,000$ was to be allocated to the Auckland Kindergarten Association for the loss of SSC support which they had previously received. It was emphasised that the package was to be a one-off contribution.

Cabinet had previously approved a $\$ 124,000$ package (CAB, 1997), but advice from the MOE, SSC and Treasury resulted in the increase. One of the key reasons for recommending it was that the initial sum was insufficient should new employer groupings emerge. The emergence of smaller employer groupings and an increased number of collective employment contracts to meet their needs was seen as desirable, in line with the new ideology.

\section{Reactions and Perspectives}

Reaction to the introduction of the Bill was swift. Labour and the Alliance released press statements condemning the move. Labour referred to the use of urgency as a "constitutional outrage" (Labour Party Press Release, April 29, 1997). The Alliance declared that the Government's actions were "tantamount to declaring war on kindergartens" (Alliance Party Press Release, April 29, 1997). NZEI was "appalled not only by the decision, but also the process used to push it through." The use of urgency procedures to "avoid public scrutiny through the Select Committee process" was described as "a serious misuse of ministerial power" (NZEI Press Release, April 29, 1997). In a letter to kindergarten staff and parents, the Executive Director of the Wellington Region Free Kindergarten Association announced that he was "dismayed by the announcement and stunned at the undemocratic process" (April 29, 1997). Kindergarten teachers nationwide made their concerns known, writing and meeting with Members of Parliament, listening to the debate in the House and seeking support for the NZEI petition.

The papers obtained under the Official Information Act from the Cabinet Committee on Education and Employment Policy (see above) revealed some interesting perspectives on the move. It appeared that the SSC was also in favour of the removal of kindergartens from the Act. Its view was that NZEI and the kindergarten associations had gained advantageous funding from Government in the 1996 CEC round, and it surmised that in 1997 NZEI was likely to pursue a claim for pay parity with vigour. The SSC believed that the timing of the introduction of the amendment was crucial and preferred that its introduction be after settlement of the 1997 CEC. The extremely short timeframe was viewed as problematic and, if delayed, the amendment could be tied to other impending changes to the State Sector Act 1988 (SSC, 1997a). It was recognised by the SSC, however, that there were some advantages to using urgency. These included the fact that Government would be removed from "any statutory role in what is likely to be an extremely difficult and protracted set of wage negotiations in 1997." On the issue of the assistance package, the SSC preferred a cash payment rather than 
offering the support of an SSC advocate. The offer of an SSC advocate, it was feared, would be publicly exploited by NZEI, suggesting "that the SSC and hence Government, was still directly involved in negotiations" (SSC, 1997b).

The Treasury clearly favoured swift removal of kindergarten teachers from the State Sector Act, and believed that only minor amendment to legislation was required. Its officials expressed concern that the EEP initially agreed to defer the decision until after settlement of the 1997 CEC, and urged action, believing that any moves in this area would become more difficult over time (Treasury, 1997a). Like the SSC, the Treasury was opposed to the assistance package involving SSC support, recommending a clean break. On April 18, 1997, it recommended increasing the assistance package from $\$ 124,000$ to $\$ 236,000$ to encourage the emergence of new employer groupings (Treasury, 1997b).

The MOE supported the removal of kindergartens from the Act, stating that this "would reduce the Government's fiscal risk in the medium to longer term." It advanced the view that kindergarten funding was a "subsidy only" and that associations had the opportunity to increase their funding by charging fees or opening for more sessions. The MOE stated, "through their own policies [associations] restrict themselves to a specific bargaining position" (MOE, 1997a). On the issue of the assistance package the MOE recommended, as did Treasury, that the sum be increased to $\$ 236,000$ to encourage new employer groups to emerge.

A submission to the EEP from the Minister of State Services revealed that officials agreed that kindergarten removal from the State Sector Act will apply "pressure to kindergarten associations to modernise and change their management structures and operating systems sooner rather than later" (SSC, 1997b).

\section{Subsequent Moves}

After the passing of the State Sector Amendment Act 1997, the Associate Minister of Education announced on June 9, 1997, that early childhood funding would receive a 5 percent "across the board" increase in the 1997 Budget. This would increase the kindergarten hourly funding rate from $\$ 3.09$ to $\$ 3.24$ per child/hour. In an interview, he admitted that one of the reasons urgency was used was to avoid potential disruptions (NZEI, 1997).
In September, 1997, Liz Gordon (Alliance Education Spokesperson) introduced a Private Members Bill to reinstate kindergarten teachers into the State Sector Act. This was unsuccessful.

In the eight months following the removal of kindergarten teachers from the State Sector Act 1988, there have been some significant moves. Negotiations between NZEI and kindergarten associations over collective employment contracts have been difficult. Associations were unable to reach agreement amongst themselves, and have negotiated in four separate groups.

The Central North Island Kindergarten Association has announced that it will charge fees in the 1998 year.

In October the Green Paper on Teacher Education was released (New Zealand Government, 1997) and kindergarten teachers were not mentioned.

The Education and Science Select Committee has heard submissions on the State Sector Act petitions organised by NZEI. A total of 377 petitions were received, containing 11,732 signatures. No date has been set for the Committee to report back to Parliament.

In November, 1997, following a conference of the New Zealand Federation of Free Kindergartens (NZFFK), the Auckland Kindergarten Association (AKA) withdrew from the group, leaving the Central North Island, Waikato, and Wellington Associations as the only remaining members. This further fragmented the national network of associations, which now included three groups: the NZFFK, the New Zealand Kindergarten Associations and the AKA.

Papers released after the passing of the State Sector Amendment reveal that the Minister of Education has considered amending the Education Act to remove kindergarten teachers from the compulsory requirement for teacher registration. These papers also showed that discussions about the transfer of kindergarten properties to associations are progressing (MOE, 1997b).

\section{Conclusion}

It is apparent that the history of prolonged and difficult negotiations in the kindergarten sector, combined with the success of the sector in using these to gain increases to funding, had won the kindergarten movement no friends in Government or official circles. That they had managed to do so previously ran contrary to the Government funding policy for the early childhood sector, which was for a neutral approach 
across the services. It was also contrary to Government's aim of devolving responsibility to regional kindergarten associations and encouraging them to operate like other fee-charging, private services.

The inclusion of kindergartens in the State Sector Act 1988 had proved to be a major stumbling block in the imposition of the New Right agenda on the kindergarten sector. It afforded kindergartens protection, emphasised Government's responsibility for funding, and enabled associations to resist changes to operation.

The Amendment to the State Sector Act passed on April 30, 1997, was a decisive move designed to eliminate Government responsibility for the forthcoming collective employment negotiations and for future claims for preferential funding and, in the longer term, to force kindergarten associations to charge fees and operate like other private early childhood services. These moves, coupled with the transfer of properties to associations and the removal of compulsory teacher registration for kindergartens, would thus open the way for the kindergarten sector to be privatised at some time in the future.

\section{References}

Bolger, J., Richardson, R., \& Birch, W. (1990). Economic and social initiative. Wellington: State Services Commission.

Cabinet. (1997, April 14). Removing the State Services Commission from wage bargaining responsibility in the kindergarten sector. CAB (97) M13/10.

Cabinet Committee on Education and Employment Policy (EEP). (1997, February 26). The management of industrial relations in the compulsory and kindergarten sectors. EEP (97) M1/2.

Consultative Committee on Pre-School Services. (1947). Report of the Consultative Committee on Pre-School Services (The Bailey Report). Wellington: Government Printer.

Crocombe, G., Enright, M., \& Porter, M. (1991). Upgrading New Zealand's competitive advantage. Auckland: New Zealand Trade Development Board and Oxford University Press.

Early Childhood Care and Education Funding Review Committee. (1991). Early childhood care and education funding review. Wellington: Ministry of Education.

Early Childhood Care and Education Working Group. (1988). Education to be more. Wellington: Government Printer.

English, W. (1996, July 27). Speech to the NZFKA Annual Conference.
Kelsey, J. (1993). Rolling back the state: Privatisation of power in Aotearoa/New Zealand. Auckland: Bridget Williams Books.

Kelsey, J. (1995). The New Zealand experiment, a world model for structural adjustment? Auckland: Auckland University with Bridget Williams Books.

Lange, D. (1988). Before five: Early childhood care and education in New Zealand. Wellington: Government Printer.

Lauder, H., (1990). The New Right revolution in New Zealand. In S. Middleton, J. Codd, \& A. Jones (Eds.), New Zealand education policy today. Wellington: Allen and Unwin.

Luxton, J., (1994, July 29). Address to the NZFKA Annual Conference.

May, H. (1997). The discovery of early childhood. Auckland: Auckland University Press, Bridget Williams Books and Wellington: New Zealand Council for Educational Research.

Minister of State Services. (1997a, March 26). Removing the State Services Commission from wage bargaining responsibility in the kindergarten sector. Wellington: SSC.

Minister of State Services. (1997b). Memorandum for Cabinet Committee on Legislation and House Business. State Sector Amendment Bill (Kindergarten Associations). Undated paper.

Ministry of Education. (1995). Status of kindergarten employees: A report for the Education and Science Select Committee. Wellington: Ministry of Education.

Ministry of Education. (1997a, March 19). Kindergarten Sector CEC negotiations: Briefing note. Wellington: Ministry of Education.

Ministry of Education. (1997b, April 24). State Sector Act Amendment: Policy issues. Wellington: Ministry of Education

Ministry of Education. (1997c). Early childhood statistics in 1997. Vol. 1, No. 11.

Mitchell, L. (1996). Crossroads - Early childhood education in the mid-1990s. New Zealand Annual Review of Education, 5, 75-92.

New Zealand Educational Institute. (1995). Submission to the Education and Science Select Committee: Funding for kindergartens. Wellington: NZEI.

New Zealand Educational Institute. (1997, June 17). Government Feared NZEI Clout. Rourou, 8(6), 2.

New Zealand Government. (1997). Quality teachers for quality learning: A review of teacher education. Wellington: Ministry of Education.

State Services Commission. (1997a, March 24). Kindergartens and the State Sector Act. Wellington: State Services Commission. 
State Services Commission. (1997b, April 9), Kindergarten issues: Paper 3 - Material from CCEEP. Wellington: State Services Commission.

Treasury. (1987). Government management: Brief to the incoming government, Vol. 2: Education issues. Wellington: Government Printer.

Treasury. (1997a, April 4). Cabinet Agenda Item 5C: Report of the Cabinet Committee on Education and Employment Policy: Week ended April 4, 1997, T97C/773. Wellington: The Treasury.

Treasury. (1997b, April 18). Cabinet Agenda Item 14: State Sector Act Amendment (Removing kindergartens from the State Sector Act) Assistance package to kindergartens. T97C/986. Wellington: The Treasury

Wylie, C. (1992). First Impressions: The initial impact of salary bulk funding on New Zealand kindergartens. Wellington: New Zealand Council for Educational Research.

\section{The author}

Claire Davison is a Senior Teacher for the Wellington Region Free Kindergarten Association. She has had experience working in the kindergarten sector, and holds an MEd from Victoria University of Wellington. Her research interests include early childhood policy, with a particular interest in its application to the kindergarten movement. 